\title{
Scientific data on selenium status in Turkey
}

\author{
Filiz Karadas
}

Department of Animal Science, Faculty of Agriculture, Yüzüncü Y1l University, Van, Turkey;

*Corresponding Author: fkaradas@yyu.edu.tr

Received 13 December 2013; revised 14 January 2014; accepted 25 January 2014

Copyright (C) 2014 Filiz Karadas. This is an open access article distributed under the Creative Commons Attribution License, which permits unrestricted use, distribution, and reproduction in any medium, provided the original work is properly cited. In accordance of the Creative Commons Attribution License all Copyrights (C) 2014 are reserved for SCIRP and the owner of the intellectual property Filiz Karadas. All Copyright (C) 2014 are guarded by law and by SCIRP as a guardian.

\section{ABSTRACT}

This review provides a summary of the available scientific data on selenium status in Turkey. The first reports regarding selenium status in Turkey appeared in the 1990s. Since then, much attention has been paid to selenium content in soil, cereal crops and a variety of other foodstuffs including corn, garlic, mushrooms, fresh and canned fish, meat and meat products, milk and dairy products, spice and condiment plants and honey. Previous reports by Foster and Summer (1997), Aras et al. (2001) and Hıncal (2007) reported daily selenium intake in Turkey to be $\mathbf{3 0}$ $\mu \mathrm{g} /$ day, 20 - $53 \mu \mathrm{g} / \mathrm{day}$ and $30-40 \mu \mathrm{g} /$ day, respectively. However, these reports are based on limited local data and cannot be generalized for the entire country. As a result, there is still a need for further research in all seven regions and 81 provinces of the country to measure selenium content of soil, food, water and animal feed in order to determine the average daily selenium intake of animals and humans in Turkey.

\section{KEYWORDS}

\section{Se; Distribution; Soil; Food; Feed}

\section{INTRODUCTION}

The biological roles ascribed to selenium (Se) including the prevention of cancer (Combs \& Lu, 2001) cardiovascular disease (Rayman, 2002, Beckett et al., 2004) and viral mutation (Beck 2001). In addition, the trace element is essential for optimal endocrine and immune function and moderating the inflammatory response (McKenzie et al., 2002, Arthur et al., 2003). Recent evidence points to a role for selenium compounds as well as seleno-proteins in the prevention of some forms of cancer [1]. Unlike other metal elements that interact with proteins in form of co-factors, selenium becomes cotranslationally incurporated into the poly-peptide chain as part of the amino acid selenocysteine (Sec). The entry point of selenium in animals is via plants, which absorb the element in its inorganic form from the soil. On a global scale, selenium availability in the soil varies between areas. Low selenium content is observed in volcanic regions and in regions with "acid soil", such as the south-eastern parts of the United States $(239,298)$ [2].

The official documentation of Turkey's selenium (Se) status is relatively poor in comparison with other countries, with little detailed information available regarding the Se content of soil or foodstuffs [3]. By comparison, the government of Canada, for example, has published Canadian Soil Quality Guidelines for Se [4], the UK government conducts monitoring and provides recommendations related to Se intake (Ministry of Agriculture, Fisheries and Food [5], and both Finland and New Zealand have carefully monitored their countries' Se status. All of these countries have also supported the use of Se in fertilizers on a national scale [6,7]. Earlier publications have reported Se soil concentrations in Turkey to be lower than those of other countries [8,9] and also it has been reported daily selenium intake in Turkey to be $30 \mu \mathrm{g} / \mathrm{day}, 20$ $53 \mu \mathrm{g} /$ day and 30 - $40 \mu \mathrm{g} /$ day, respectively [10-12].

An interesting study by Aras and Kumpulainen [13] measured the Se content of Turkish wheat from four different regions in 1986, 1987, 1990, 1992, 1993 and 1994 and reported a mean Se value of $32 \mu \mathrm{g} / \mathrm{kg}$, whereas Cankur [14] reported wheat products from the same three regions to have an average Se value of $89 \mu \mathrm{g} / \mathrm{kg}$ between 1995 and 1996. With regard to these differences, it should be noted that Se content in soil is a reflection of the atmospheric and anthropogenic weathering of parent materials and is thus widely variable, even at different times in the same area [15]. A research conducted in the same areas during 1997 and 1998 measured Se levels in 
wheat using spectrofluorometry and found a mean value of $81 \mu \mathrm{g} / \mathrm{kg}$. In the same study, corn samples from local markets in the Eastern Black Sea Region were found to have an average Se content of $52 \mu \mathrm{g} / \mathrm{kg}$, which was lower than the average of $76 \mu \mathrm{g} / \mathrm{kg}$ reported for Central Anatolia by Giray and Hincal [3].

Another interesting study was conducted by Tuzen et al. [16] to identify trace elements, including Se, in 25 honey samples from different botanical sources collected from throughout Turkey (Figure 1). The lowest Se content (38 $\mu \mathrm{g} / \mathrm{kg}$ ) was reported from Antalya (Mediterranean) and the highest Se $(113 \mu \mathrm{g} / \mathrm{kg})$ from Bursa (West Anatolia). A lack of similar studies made it impossible for the authors to compare these levels with those of honey from other countries or from other research in Turkey. Some authors have suggested that honey and other bee products could be representative bio-indicators of environmental pollution (Conti \& Botre, 2001; Leita et al., 1996; Yazgan et al., 2006). While honey may not be the most sensitive tool for the evaluation of environmental contamination from heavy metals because of the low concentrations in which these materials are present and the great variability in products due to factors including botanical origin, floral density, season and rainfall (Fredes \& Montenegro, 2006), examining the Se content of honey to gain an understanding of Se status in Turkey could prove interesting [16]. In another study by Tuzen et al. [17], the authors examined the trace element composition of mushroom species from the Eastern Black Sea Region of Turkey, collecting 48 samples that included 16 different mushrooms species from different localities within the region. The lowest Se concentrations $(0.54 \mu \mathrm{g} / \mathrm{g})$ were reported in Panellus stipticus and the highest $(10.8 \mu \mathrm{g} / \mathrm{g})$ in Amanita pantherina. The authors reported these values to be in line with studies by Piepponen, Liukkonen-Lilja, \& Kuusi (1983), Huerta, Sanchez, \& Sanz-Medel (2005), Kalač \& Svoboda (2000) and Agrahar-Murugkar \& Subbulakshmi (2005), who reported values of $0.05-37 \mu \mathrm{g} / \mathrm{g}, 1.30-21.5 \mu \mathrm{g} / \mathrm{g}, 1$ $367 \mu \mathrm{g} / \mathrm{g}$ and $0.17-975 \mu \mathrm{g} / \mathrm{kg}$, respectively.

There is no information currently available regarding maximum Se levels for fish in Turkey. However, a recent study by Tuzen and Soylak [18] examining trace element contents of canned anchovies, tuna, Black Sea bonito, sardines and trachurus trachurus purchased from major supermarket chains in Turkey found samples to be very rich in Se (Table 1). Of the various types of fish examined, the highest Se levels were found in canned Trachurus trachurus (3.64 $\mu \mathrm{g} / \mathrm{g})$ and the lowest in canned Black Sea bonito $(0.96 \mu \mathrm{g} / \mathrm{g})$.

A study of trace element contents in marine algae species collected from the Black Sea coast showed Se levels ranging from $11 \mu \mathrm{g} / \mathrm{kg}$ to $694 \mu \mathrm{g} / \mathrm{kg}$ [19].

In a recent study by Gezgin et al. [20], the Se content of various forms of black and green tea was evaluated using inductively coupled plasma atomic emission spectrometry (ICP-AES). Considering that tea is the most popular beverage in Turkey and is usually consumed on a daily basis, the results of this study are very important in terms of daily Se levels among the Turkish population. As Table 2 shows, Rize Turist black tea was found to have the highest Se levels of the various beverages tested.

Özcan [21] reported on the Se content of 32 plants used as spices and condiments in Turkey (Table 3). Samples were purchased from open markets in the Central Anatolian city of Konya. While the majority of plants tested had no detectable levels of Se, mustard, black cumin and parsley were found to have high levels of Se.

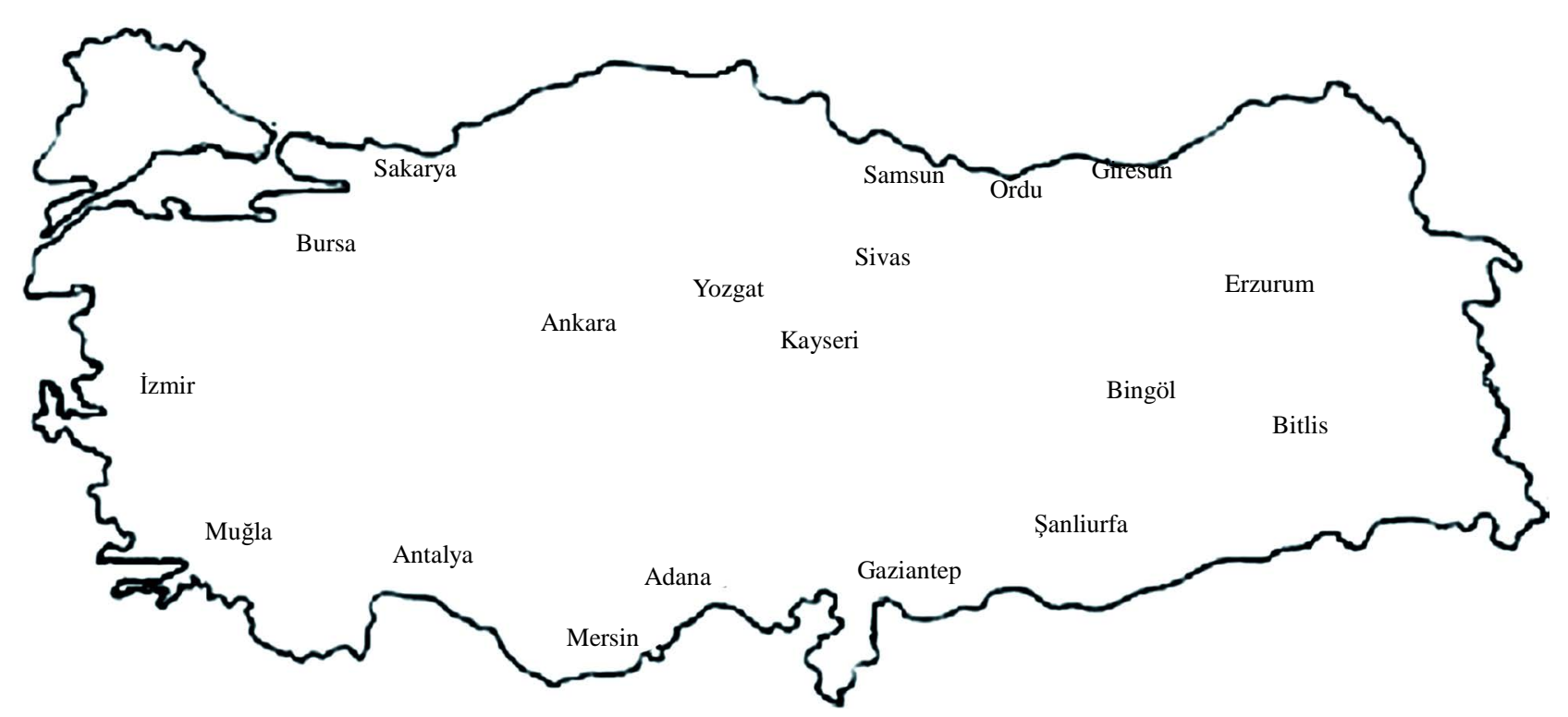

Figure 1. Honey samples collected from different cities of Turkey (Adapted from Tuzen et al., 2007a). 
Table 1. Selenium content of canned fish samples from Turkey (adapted from Tuzen and Soylak, 2007).

\begin{tabular}{cc}
\hline Sample & $\mu \mathrm{g} / \mathrm{g}, \mathrm{N}=4$ \\
\hline Canned anchovy fish & $1.30 \pm 0.10$ \\
Canned tuna fish & $2.98 \pm 0.25$ \\
Canned Black Sea bonito & $0.96 \pm 0.07$ \\
Canned sardine & $2.77 \pm 0.20$ \\
Canned trachurus trachurus & $3.64 \pm 0.32$ \\
\hline
\end{tabular}

Table 2. Selenium contents (ppm) of hot water extract (infusion) obtained from several commercial Turkish Teas (adapted from Gezgin et al., 2006).

\begin{tabular}{ccccc}
\hline Manufacturer & Tea types & $\begin{array}{c}\text { Se content (ppm) } \\
\text { hot water extract } \\
\text { (infusion) }\end{array}$ & $\begin{array}{c}\text { Se content (ppm) } \\
\text { Incinerated in } \\
\text { microwave oven }\end{array}$ & $\begin{array}{c}\text { Percentage (in ppm) of Se } \\
\text { extracted from tea leaves to hot water } \\
(2.5 \mathrm{~g} / 50 \mathrm{~mL})\end{array}$ \\
\hline & Rize turist & $0.47 \pm 0.17$ & $0.27 \pm 0.28$ & 175.62 \\
$\begin{array}{c}\text { Çaykur Co. } \\
\text { (Rize, Turkey) }\end{array}$ & Tea flower & $0.26 \pm 0.31$ & $0.69 \pm 0.65$ & 37.82 \\
& Young shoots & $0.54 \pm 0.12$ & $0.61 \pm 0.53$ & 87.95 \\
$\begin{array}{c}\text { DOGADAN Co. } \\
\text { Tea buds }\end{array}$ & $0.56 \pm 0.05$ & $0.65 \pm 0.31$ & 86.62 \\
(Balgat-Ankara, Turkey) & Geapots bags & $0.59 \pm 0.01$ & $0.64 \pm 0.89$ & 86.88 \\
\hline
\end{tabular}

A study by Demirezen and Uruç [22] used ICP-AES to identify the Se content in a total of 34 samples including 11 varieties of fish, meat and meat products representing approximately $80 \%-90 \%$ of the fish, meat and meat products traditionally consumed in Turkey. Samples were obtained from local shops and producers in Kayseri during 2003 and 2004. Se levels were as follows: soudjouck, $3.9 \pm 0.89 \mu \mathrm{g} / 100 \mathrm{~g}$; salami, $1.6 \pm 0.98 \mu \mathrm{g} / 100 \mathrm{~g}$; sausage, $1.8 \pm 0.6 \mu \mathrm{g} / 100 \mathrm{~g}$; pastirma, $4.6 \pm 0.5 \mu \mathrm{g} / 100 \mathrm{~g}$; meat, 3.2 $\pm 0.99 \mu \mathrm{g} / 100 \mathrm{~g}$; minced meat, $1.6 \pm 0.7 \mu \mathrm{g} / 100 \mathrm{~g}$; Pomatomus saltatrix (blue fish), $3.68 \pm 0.7 \mu \mathrm{g} / 100 \mathrm{~g}$; Micromesistius poutassou (mackerel), $1.32 \pm 2.98 \mu \mathrm{g} / 100 \mathrm{~g}$; Saurel, Engraulis encrasicholus (anchovy), $3.3 \pm 0.8$ $\mu \mathrm{g} / 100 \mathrm{~g}$; Gadus euxina (blue whiting), $1.8 \pm 0.9 \mu \mathrm{g} / 100 \mathrm{~g}$; Sarda sarda (bonito), $2.3 \pm 0.98 \mu \mathrm{g} / 100 \mathrm{~g}$. Mean concentrations of Se in fish $(2.8 \mu \mathrm{g} / 100 \mathrm{~g})$ were similar to values recommended by the World Health Organization (2.55 $\mu \mathrm{g} / 100 \mathrm{~g}$ ) for Turkey (WHO, 1992), and mean concentrations of Se in meat and meat products $(2.8 \mu \mathrm{g} / 100 \mathrm{~g})$ exceeded those reported by the World Health Organization (1.6 $\mu \mathrm{g} / 100 \mathrm{~g})(\mathrm{WHO}, 1992)$ [22].

Beytut et al., [23] examined the Se contents in soil, meadow hay and sheep heart and gluteal muscles in the Kars region, a major sheep-rearing area in Turkey and one where there is a high lamb mortality rate due to white muscle disease (WMD). Se levels in soil and meadow hay collected from the disease foci were found to be $0.03 \mathrm{ppm}$ and $0.07 \mathrm{ppm}$ (dry weight), respectively. The authors noted that these levels were low in comparison to the literature, which included reported soil levels of 0.1 (Bostedt \& Schramel, 1990) and $2.0 \mathrm{ppm}$ Andres et al. (1997) and pasture and forage levels of at least $0.1 \mathrm{ppm}$ (McDowell, 1992).

Se contents in milk and other dairy products from the Central Anatolian Region of Turkey have been reported on by Ayar et al. [24] (Table 4); no discernible Se contents were detected in ice cream, milk powder, whey powder or yogurt samples. The highest average Se content was found in Tulum cheese $(0.43 \mathrm{mg} / \mathrm{kg})$, followed by butter $(0.315 \mathrm{mg} / \mathrm{kg})$. The authors reported that the Se contents in milk, butter, white cheese, yellow cheese and Tulum cheese consumed in Turkish society on a daily basis was higher than the RDA [24].

Demirel et al. [25]; have provided assessments of the Se content of a variety of commonly consumed fresh and canned foods from the Central Anatolian city of Tokat (Table 5). Of the various samples tested, the highest Se levels were found in tomato sauce $(0.801 \mu \mathrm{g} / \mathrm{g})$ and the lowest in beer $(0.026 \mu \mathrm{g} / \mathrm{mL})$. The authors also reported a Se level of $151 \mathrm{ng} / \mathrm{g}$ in garlic, which was lower than a previous study by Inam and Somer (1999), which reported a range of 365 - $485 \mathrm{ng} / \mathrm{g}$.

Turkish hazelnuts have, in general, been reported to have a high Se content. A study by Dundar and Altuntag [26] examined the Se content of three different varieties of hazelnut cultivated in the Kocaali, Karasu, Akyazı, 
Table 3. Selenium content of plants (adapted from Özcan 2004).

\begin{tabular}{|c|c|}
\hline Plant name & Selenium content (mg/kg) \\
\hline Cumin & 1.41 \\
\hline Dill & 1.65 \\
\hline Mint & 1.12 \\
\hline Savory & 0.15 \\
\hline Mustard & 5.03 \\
\hline Sage & 1.44 \\
\hline Caraway & - \\
\hline Mahleb & - \\
\hline Capers & - \\
\hline Fennel (bitter) & 2.05 \\
\hline Thyme & 1.50 \\
\hline Laurel & 0.17 \\
\hline Black, thyme & 2.52 \\
\hline Mountain tea & - \\
\hline Sumac & - \\
\hline Lavender & - \\
\hline Melisa & - \\
\hline Coriander & 2.46 \\
\hline Fennel (sweet) & 0.48 \\
\hline Fenugreek & - \\
\hline Black cumin & 3.24 \\
\hline Paprika & 0.72 \\
\hline Anise & 2.02 \\
\hline Basil & - \\
\hline Rosemary & - \\
\hline Oregano & - \\
\hline Capsicum & 1.80 \\
\hline Sahlep & 2.48 \\
\hline Pickling herb & 2.23 \\
\hline Girit savory & 1.51 \\
\hline Parsley & 3.21 \\
\hline Рорру & 2.88 \\
\hline
\end{tabular}

Table 4. The average selenium content $(\mathrm{mg} / \mathrm{kg})$ of milk and dairy products in middle Anatolia (Adapted from Ayar et al., 2009).

\begin{tabular}{cc}
\hline Milk and dairy products & Se $(\mathrm{mg} / \mathrm{kg})$ \\
\hline Milk & $0.23 \pm 0.12$ \\
Butter & $0.32 \pm 0.35$ \\
Ice cream & n.d. \\
Milk powder & n.d. \\
Whey powder & n.d. \\
Yogurt & n.d. \\
Drained yogurt & $0.08 \pm 0.15$ \\
Ayran & n.d. \\
White cheese (Beyaz) & $0.16 \pm 0.00$ \\
Yellow cheese (Kaşar) & $0.28 \pm 0.00$ \\
Tulum cheese & $0.43 \pm 0.75$ \\
Lor cheese & n.d. \\
\hline
\end{tabular}

Table 5. Selenium content of some foods from Tokat (Adapted from Demirel et al., 2008).

\begin{tabular}{cc}
\hline Selected food samples & Se level $(\mu \mathrm{g} / \mathrm{g})$ \\
\hline Tomato sauce 1 & $0.331 \pm 0.02$ \\
Tomato sauce 2 & $0.801 \pm 0.06$ \\
Rice & $0.092 \pm 0.01$ \\
Chickpea & $0.095 \pm 0.01$ \\
Bulgur & $0.082 \pm 0.01$ \\
Walnut & $0.028 \pm 0.00$ \\
Hazelnut & $0.054 \pm 0.00$ \\
White seed & $0.106 \pm 0.01$ \\
Black seed & $0.132 \pm 0.01$ \\
Pumpkin seed & $0.370 \pm 0.02$ \\
Garlic & $0.151 \pm 0.01$ \\
Pistachio & $0.103 \pm 0.01$ \\
Biscuit & $0.072 \pm 0.01$ \\
Mushroom & $0.241 \pm 0.02$ \\
Beef & $0.381 \pm 0.03$ \\
Chicken & $0.188 \pm 0.01$ \\
Milk 1 & $0.070 \pm 0.01$ \\
Milk 2 & $0.082 \pm 0.01$ \\
Red wine & $0.030 \pm 0.00$ \\
Beer & $0.026 \pm 0.00$ \\
\hline
\end{tabular}


Hendek, and Ferizli districts of the province of Sakarya in the Marmara Region of Turkey during the 2001 harvesting season. Mean Se levels of unhulled and hulled Kara Findık, Tombul and Delisava hazelnut varieties were found to be $4.7 \mu \mathrm{g} / \mathrm{g}$ and $7.0 \mu \mathrm{g} / \mathrm{g}, 3.6 \mu \mathrm{g} / \mathrm{g}$ and 9.5 $\mu \mathrm{g} / \mathrm{g}$, and $16.9 \mu \mathrm{g} / \mathrm{g}$ and $6.6 \mu \mathrm{g} / \mathrm{g}$, respectively. The difference in Se content between hulled and unhulled hazelnut kernels as well as the differences in Se content among regions were found to be statistically significant. The highest Se levels were observed in hulled Tombul hazelnuts from Ferizli, and the lowest Se levels were observed in unhulled Kara Findık and Tombul hazelnuts from Karasu. Another study by Simsek and Aykut [27] examined Se content in 16 hazelnut varieties collected in 2002 by the Hazelnut Research Institute from the provinces of Ordu and Giresun in the Black Sea Region. Reported Se levels $(0.96-1.39 \mu \mathrm{g} / \mathrm{g})$ were significantly lower than those reported by Dundar and Altuntag [26].

Most of the above-mentioned reports indicate low Se levels in the Black Sea Region. This could be due to low soil selenium levels in the region, which has consistently high rainfall, which could result in leaching of minerals from the soil to the sea.

\section{BLOOD SELENIUM LEVELS AMONG THE TURKISH POPULATION}

In their first report on the Se levels among the Turkish population, Hincal et al [28] found a mean blood Se level of $88 \pm 12 \mu \mathrm{g} / \mathrm{l}$ serum among a population of 76 middle-to-upper-middle-income children living in Ankara. A subsequent study by Hincal et al. [29] conducted among a socio-economically heterogeneous population of 218 subjects from urban Ankara reported mean Se levels of $45 \pm 10 \mu \mathrm{g} / \mathrm{l}$ in cord blood at birth, $74 \pm 14 \mu \mathrm{g} / \mathrm{l}$ in children aged 2 - 16 years and $74 \pm 16 \mu \mathrm{g} / \mathrm{l}$ in adults aged 18 48. In an extended study by Giray and Hincal [3] conducted in all seven geographical regions of Turkey, the authors reported a mean Se plasma level of $71 \pm 15 \mu \mathrm{g} / \mathrm{l}$ among 274 subjects aged 19 - 61 years randomly selected from middle to middle-upper income families. No Se deficiency was observed in any region, although the Black Sea Region had the lowest mean Se level (Table 6). Similar results were obtained by Mengubas et al. [30] who measured Se plasma levels in 250 school-age children from four different regions of Turkey and found mean levels of $75 \pm 9 \mu \mathrm{g} / \mathrm{l}$ for boys and $65 \pm 10 \mu \mathrm{g} / \mathrm{l}$ for girls. Two other studies of schoolchildren were conducted by Isbir et al. [31,32]. The first study, conducted in Adana, reported serum Se levels of $0.73 \pm 0.11 \mu \mathrm{mol} / 1$ and $0.92 \pm 0.10 \mu \mathrm{mol} / 1$ among children aged $7-8$ years and 11 - 12 years, respectively. The second study, conducted in Konya, reported a similar level among 600 healthy children aged 7 - 12. Our own research Ozdemir et al. [33]
Table 6. Plasma selenium levels of adults (19 - 61 years old) from different geographical region of Turkey (adapted from Giray and Hincal, 2004).

\begin{tabular}{cccc}
\hline Region & $\mathrm{N}$ & $\mathrm{Se}, \mu \mathrm{g} / 1$ & Range \\
\hline Central Anatolia & 80 & $71 \pm 11$ & $51-96$ \\
Black Sea & 100 & $66 \pm 17$ & $28-114$ \\
West & 26 & $58 \pm 15$ & $28-85$ \\
Middle & 25 & $58 \pm 17$ & $35-93$ \\
East & 49 & $75 \pm 15$ & $42-114$ \\
Marmara & 63 & $72 \pm 10$ & $54-96$ \\
Thrace & 30 & $69 \pm 90$ & $55-88$ \\
Southern & 33 & $75 \pm 10$ & $54-96$ \\
Mediterranean & 31 & $78 \pm 16$ & $51-110$ \\
Overall & 274 & $71 \pm 15$ & $28-114$ \\
\hline
\end{tabular}

conducted in the Van Basin in Eastern Turkey, found a mean plasma Se level $68.52 \pm 3.57 \mathrm{ng} / \mathrm{ml}$ among 30 pregnant women aged $26.4 \pm 2.1$ years. This value is much higher than that reported in a study among pregnant women in the Central Anatolian province of Kayseri, which found a mean Se value of $35.14 \pm 6.71 \mathrm{ng} / \mathrm{ml}$ (range: 23.22 - $53.86 \mathrm{ng} / \mathrm{ml}$ ). Kilinc et al. [34] reported that se blood level of Women with 10 - 14 of gestational weeks was $44.85 \pm 9.23$; in 16 - 20 weeks of gestation was $47.18 \pm 10.92$; in non-pregnant women was $55.38 \pm$ 8.81 respectively in Kahramanmaras. According to report of Dobrzynskia et al., 1998; for optimum balance of pregnancy at least $100 \mathrm{mg}$ dietary Se is needed. Therefore reported results $(47.18 \mathrm{ng} / \mathrm{ml})$ from Kahramanmaras almost the half of the needed level of Se pregnancy (at least $100 \mathrm{mg}$ dietary).

\section{CONCLUSION}

This review is the first to report on all published information available on Se status in Turkey, including Se levels in soils, foods and human plasma. The Se cycle begins and ends with the soil, with the need for Se supplements among human or animal populations based on the chemical composition and Se concentrations in soil. However, currently available data on Se intake in humans and Se soil levels are based on limited, local data that cannot be generalized to the Turkish population and area as a whole. Therefore, further studies need to be conducted to determine soil Se content for Turkey as soon as possible. Furthermore, in Turkey, most small ruminants and native cattle spend half the year grazing extensively and are not provided with supplemental feed and are thus significantly and directly affected by Se deficiencies in soil. If it is determined that Se deficiency 
is a problem in Turkey, solutions may include direct supplements for humans and animals, the addition of Se to fertilizers, as is done in some Scandinavian countries, or the coating of seeds with Se, as in Canada. Given the majority of data from the Black Sea Region, it can be expected that this population may suffer from Se deficiencies.

\section{REFERENCES}

[1] Beckett, G.J. and Arthur, J.A. (2005) Selenium and endocrine systems. Journal of Endocrinology, 184, 455-465. http://dx.doi.org/10.1677/joe.1.05971

[2] Papp, L.V., Lu, J., Holmgren, A. and Khanna, K. (2007) From selenium to selenoproteins: Synthesis, identity, and their role in human health. Antioxidants and Redox Signaling, 9, 775-806.

http://dx.doi.org/10.1089/ars.2007.1528

[3] Giray, B. and Hincal, F. (2004) Selenium status in Turkey: Possible link between status of selenium, iodine, antioxidant enzymes and oxidative DNA damage. Journal of Radioanalytical and Nuclear Chemistry, 259, 447-451. http://dx.doi.org/10.1023/B:JRNC.0000020916.24769.41

[4] Anonymous (2009) Canadian soil quality guidelines SELENIUM environmental and human health effects. Canadian Council of Ministers of the Environment 2009. http://www.ccme.ca/assets/pdf/soqg_se_scd_1438.pdf

[5] Anonymous (1997) 126: MAFF UK-Dietary intake of selenium-archive-food.

http://archive.food.gov.uk/maff/archive/food/infsheet/199 7/no126/126selen.htm

[6] Ekholm, P., Yilinen, M., Eurola, M., Koivistoinen, P. and Varo, P. (1991) Selenium in finnish foods after beginning the use of selenate-supplemented fertilizers. Journal of the Science of Food and Agriculture, 56, 57-70. http://dx.doi.org/10.1002/jsfa.2740560107

[7] Watkinson, J.H. (1987) Annual topdressing of pasture with selenate pellets to prevent selenium deficiency in grazing stock: Research and farming practices in New Zealand. In: Combs, G.F., Levander, O.A. and Spallholza, J.E., Eds., Selenium in Biology and Medicine, Van Nostrand Reinhold, New York, 783-792.

[8] Sillanpaa, M. (1982) Micronutrients and nutrient status of soils: A Global Study. FAO Soil Bulletin No. 48, Food and Agriculture Organization, Rome.

[9] Iyengar, V. and Woittiez, J. (1988) Trace elements in human clinical specimens: Evaluation of literature data to identify reference values. Clinical Chemistry, 34, 474481.

[10] Foster, L.H. and Sumer, S. (1997) Selenium in health and disease: A review. Critical Reviews in Food Science and Nutrition, 37, 211-228. http://dx.doi.org/10.1016/0003-2697(84)90371-3

[11] Aras, N.K., Nazli, A., Zhang, W. and Chatt, A. (2001) Dietary intake of zinc and selenium in Turkey. Journal of Radioanalytical and Nuclear Chemistry, 249, 33-37. http://dx.doi.org/10.1023/A:1013224010632
[12] Hincal, F. (2007) Trace elements in growth: Iodine and selenium statues of Turkish children. Journal of Trace Elements in Medicine and Biology, 21, 40-43. http://dx.doi.org/10.1016/j.jtemb.2007.09.012

[13] Aras, N.K. and Kumpulainen, J.T. (1995) Trace elements in Turkish wheat and human diets. Trace elements, natural antioxidants and contaminants in European foods and diets. Technical Workshop on Trace Elements, Natural Antioxidants and Contaminants in European Foods and Diets, Helsinki, 25-26 August 1995, 1020-3737.

[14] Cankur, O. (1998) Determination of trace elements in wheat, soil and soil extracts by instrumental neutron activation analysis and atomic absorbtion spectrometry. Master of Science Thesis, METU, Ankara.

[15] Neal, R.H. (1995) Selenium. In: Alloway, B.J., Ed., Heavy Metals in Soils, Blackie Academic and Professional, London, 260-262. http://dx.doi.org/10.1007/978-94-011-1344-1 12

[16] Tuzen, M., Silici, S., Mendil, D. and Soylak, M. (2007) Trace element levels in honeys from different regions of Turkey. Food Chemistry, 103, 325-330. http://dx.doi.org/10.1016/j.foodchem.2006.07.053

[17] Tuzen, M., Sesli, E. and Soylak, M. (2007) Trace element levels of mushroom species from East Black Sea Region of Turkey. Food Control, 18, 806-810. http://dx.doi.org/10.1016/j.foodcont.2006.04.003

[18] Tuzen, M. and Soylak, M. (2007) Determination of trace metals in canned fish marketed in Turkey. Food Chemistry, 101, 1378-1382. http://dx.doi.org/10.1016/j.foodchem.2006.03.044

[19] Tuzen, M., Verep, B., Ogretmen, A.O. and Soylak M. (2009) Trace element content in marine algae species from the black sea, Turkey. Environmental Monitoring and Assessment, 151, 363-368. http://dx.doi.org/10.1007/s10661-008-0277-7

[20] Gezgin, S., Özcan, M.M. and Atalay, E. (2006) Determination of minerals extracted from several commercial teas (camellia sinensis) to hot water (infusion). Journal of Medicinal Food, 9, 123-127.

http://dx.doi.org/10.1089/jmf.2006.9.123

[21] Özcan, M. (2004) Mineral contents of some plants used as condiments in Turkey. Food Chemistry, 84, 437-440. http://dx.doi.org/10.1016/S0308-8146(03)00263-2

[22] Demirezen, D. and Uruc, K. (2006) Comparative study of trace elements in certain fish, meat and meat products. Meat Science, 74, 255-260. http://dx.doi.org/10.1016/j.meatsci.2006.03.012

[23] Beytut, E., Karatas, F. and Beytut, E. (2002) Lambs with white muscle disease and selenium content of soil and meadow hay in the region of Kars, Turkey. The Veterinary Journal, 163, 214-217. http://dx.doi.org/10.1053/tvjl.2001.0652

[24] Ayar, A., Sert, D. and Akın, N. (2009) The trace metal levels in milk and dairy products consumed in middle Anatolia-Turkey. Environmental Monitoring and Assessment, 152, 1-12. http://dx.doi.org/10.1007/s10661-008-0291-9

[25] Demirel, S., Tuzen, M., Saracoglu, S. and Soylak, M. 
(2008) Evaluation of various digestion procedures for trace element contents of some food materials. Journal of Hazardous Materials, 152, 1020-1026. http://dx.doi.org/10.1016/j.jhazmat.2007.07.077

[26] Dundar, M.S. and Altundag, H. (2004) Selenium content of Turkish hazelnut varieties: Kara findik, tombul and delisava. Journal of Food Composition and Analysis, 17, 707-712. http://dx.doi.org/10.1016/j.jfca.2003.12.001

[27] Simsek, A. and Aykut, O. (2007) Evaluation of the microelement profile of Turkish hazelnut (Corylus avellana L.) varieties for human nutrition and health. International Journal of Food Sciences and Nutrition, 58, 677-688. http://dx.doi.org/10.1080/09637480701403202

[28] Hincal, F., Yetgin, S. and Ataceri, N. (1998) Selenium statues in Turkey. I. Serum selenium level in infants and children in Ankara. Biological Trace Element Research, 20, 161-167. http://dx.doi.org/10.1007/BF02919108

[29] Hincal, F., Basaran, N., Yetgin, S. and Gokmen, O. (1994) Selenium statues in Turkey. II. Serum selenium concentration in healthy residents of different ages in Ankara. Journal of Trace Element Electrolytes Health Disease, 8, 9-12.
[30] Mengubas, K., Diab, N.A., Gokmen, I.G., Ataman, O.Y., Cavdar, A. and Cin, S. (1996) Selenium status of healthy Turkish children. Biological Trace Element Research, 54, 163-172. http://dx.doi.org/10.1007/BF02786263

[31] Isbir, T., Taylor, A., Taner, L. and Kaleagasioglu, F. (1996) Serum selenium levels of children living in Adana, Turkey. Trace Elements and Electrolytes, 13, 136-137.

[32] Isbir, T., Taylor, A., Taner, L., Yucebilgic, G. and Oner, A. (1997) Zinc and selenium status of healthy children from the Central Anatolian region of Turkey. Trace Elements and Electrolytes, 14, 87-90.

[33] Ozdemir, H.S., Karadas, F., Pappas, A.C., Cassey, P., Oto, G. and Tuncer, O. (2008) The selenium levels of mothers and their neonates using hair, breast milk, meconium, and maternal and umbilical cord blood in Van. Biological Trace Element Research, 122, 1-10.

[34] Kilinc, M., Coskun, A., Bilge, F., Imrek, S.S. and Atli, Y. (2010) Serum reference levels of selenium, zinc and copper, in healthy pregnant women at the prenatal screening program in southeastern Mediterranean region of Turkey. Journal of Trace Elements in Medicine and Biology, 24 152-154. http://dx.doi.org/10.1016/j.jtemb.2010.01.004 